Vol. 1, Issue. 1 | January - June 2021

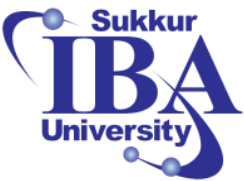

\title{
Factors Influencing Continuous Professional Development of Teacher at University Level
}

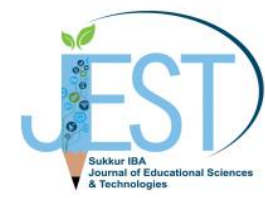

\author{
Sana Mairaj Bugti ${ }^{1}$, Muhammad Umair ${ }^{2}$, Rukshinda Basharat ${ }^{3}$ \\ ${ }^{1}$ Department of Education, Iqra University Karachi \\ Corresponding author‘s email: sana.bugti45@gmail.com
}

\begin{abstract}
This study intends to find how time, funding and head influence impact on continuous professional development of university teachers. Purposive sampling (non-probability) was used for the study and survey method was adopted. The data was collected from 225 respondents and questionnaire is used as data collection instrument and respondents belongs to a public university Shah Abdul Latif University, Khairpur Mirs' which is located in Sindh province. For hypothesis testing, structural regression model was selected. IBM SPSS is the tool we used to analyze the collected data and applied tests like Exploratory Factor Analysis (EFA) and multiple regression and AMOS is used to check Confirmatory Factor Analysis (CFA). Overall results provided the evidence that time and funding does not influence on Continuous Professional Development of university teachers while head influence significantly effecting on it. Continuous Professional Development (CPD) enhance competencies and skills of teachers that ensure the quality education therefore it is the demand of the age. This study provides an exclusive viewpoint of university teachers regarding factors influencing on continuous professional development.
\end{abstract}

Keywords: Continuous Professional Development, Professional Development, CPD Factors, Time, Funding, Head Influence, Professional Activities.

\section{Introduction}

The main element for any society is to prepare the well-educated people who are skilled enough to engage in global competition. One of the key aspect in educational process is the development of high quality teachers (Seferoglu, 2007; Borko, 2004). Porter, Birman, Garet and Desimone, (2000) add that professional development activities are important to prepare such high quality educators and also helps in improving the quality education of institution (Borko, 2004). Bredson, (2003) portrayed the same thoughts that educators' reflective and creative skills are enhanced through CPD trainings.

Professional Development is infinite upgradation to support and boost up professional competencies, skills and practices. Continuous Professional Development (CPD) is assurance of progressing, continuing and expansion of specific skills required for quality education. Day (1993), Showers and Joyce (1995), Hirsch and Sparks (1997), Gaunt (1997) and Hewson, Loucks-Horsley, Stiles and Love (1998) presented their viewpoint by indicating that to be successful for implementing different reforms in educational system and focusing on students' learning teacher needs to be professionally skilled. While Bredeson and Scibner, (2000) indicated time, resources and support of different individuals as crucial factors for professional development practices. The lack of any of above factors affect learning activities and provision of these all foster and flourish knowledge in professional practices.

In Pakistan, almost all teachers at primary, secondary and high school level have to attain pre-service or inservice teacher's professional development program but at university level there is no condition of any professional training to get the job. On the other hand, for in-service teachers there is no any proper framework for professional development activities in university context. Considering the current factual condition this research intends to determine the factors influencing continuous professional development (CPD) of university teachers.

\section{Literature Review}

Professional development programs enhance teachers' competencies and enable them to be a helping hand for new ones (Porter, Birman, Garet \& Desimone 2000). Similarly, many of the researchers (Gless \& Moir, 2001; Dikici \& Boydak, 2001; jonson, 2002; Yoon, Garet, Birman, Porter \& Desimone, 2002; Kartz \& 
Carver, 2004; Talbert \& McLaughlin, 2006) asserted that teachers' performance is positively affected by high quality professional development activities within or beyond the institute. On the other hand Hirsch and Sparks (1997) talked about the policy makers and practitioners and mentioned that both are focusing on teacher's professional development. Bredeson, (2002) provided evidence in his study about policy statements, research reports and legislative mandates in United States and Europe to support the crucial role of continuous professional development programs for enhancement of teachers' competencies. CPD also helps to improve the inappropriate behaviour and attitude of the teachers (Le Metais, 1997) and also enhance their abilities to successfully implement the reforms (Bredeson, 2003). Hence, updated subject matter knowledge and skills are crucial for the educators to integrate current knowledge with the prior professional practices by attending different continuous professional development programs and actively participating in professional activities. Moreover, Bredeson and Scibner (2000) asserted that different factors i.e. time, resources and support of head of institute play vital role for accomplishment of all professional development activities.

In conducting this research, the researcher therefore addressed the questions; what are the factors that influence the CPD of university teachers? For instance, how do time, funding and head of department influence participation of educators in professional development programs? However, this study focused to explore the factors that influence university teachers' participation in professional development programs.

\subsection{Development of Hypothesis}

Time: Time is considered as first and foremost factor as found by Lohman (2006), affecting continuous professional developing of teachers. Nowadays, teachers' workload and responsibilities are increased other than to teach the students. It indicates that the educators have very limited time to take part in continuous professional development practices due to spending all their time on teaching related tasks (Vaughn, Arguelles, Hughes \& Klinger, 1999; Hodkinson \& Hodkinson, 2005). Many of the studies have clearly shown that the most influential component which affects teachers' participation in continuous professional development trainings is time (Demirtas, 2010; Visser et al., 2010; Haudenschild \& Yamagata-Lynch, 2009; Easton, 2008; Rogers et al., 2007; Scribner \& Sandholtz, 2006; Lindsay, Muijs \& Goodall, 2005; Klinger, 2004; Cook \& Collinson, 2004; Guskey, 2003; Kwakman, 2003; Richardson, 2003; Nijhof, Nieuwenhuis \& Van woerkom, 2002; Hirsh \& Harris, 2001; Collinson, 2000; Guskey, 1999, Akkoyunlu \& Orhan, 1999; Zeuli \& Thompson, 1999; Klingner et al., 1999; Richrdson, 1997; Noden \& Moss, 1994; Castle \& Watts, 1993; Rosenholz, 1989). Similarly, Postholm (2011) illustrated that lack of time is an obstacle for teachers to take part in the programs related to continuous professional development. Valentine (1997) and Schnlan (1986) have also stated that teachers' participation in teaching and teaching related tasks is affected by incapability of time. Moreover, the study of Cook and Collinson (2000) found that the most probable hindrance is shortage of time that causes the low participation of teachers in CPD activities. As the result, the underlying hypothesis is proposed:

\section{H1: Time influence the teachers' participation in Continuous Professional Development activities.}

Funding: Funding refers to financial support and it plays an important role in teachers' participation for continuous professional development activities (Richardson, 1997; Lohman, 2006) rather than only designing and implementing them (Postholm, 2011; Corcoran, 1995). Many of the studies had focused the importance of funding for teachers participation in professional development programs (Birman et al., 2000; Corcoran, 1995; Richardson, 2003; Howey \& Hering 1982; Turney \& Abadiano, 2004). Valentine (1997) concluded that it affects the decisions of the teachers either to take part in professional development programs or not. Researchers argued that funding is the main component for teachers' motivation to take part in programs of professional development (Shafer, 2009; Easton, 2008). The skills of professional teachers may be funded and teachers are allowed to have the duty leave. It strengthens the participation of teachers in professional development practices (Hodkinson \& Hodkinson, 2005). Leanard and Leonard (2003) supported the idea of Hodkinson and Hodkinson (2005) for improving teachers' professional development and asserted that funding is the chief concerned for teachers' professional development activities within and outside the school context. This leads to following hypothesis:

H2: Funding influence teachers' participation in Continuous Professional Development activities.

Head Influence: Head of institution had an abundant influence on participation of teachers in CPD programs. Mclaughlin and Talbert, (2006) portrayed the idea that head is the one who can encourage or discourage the environment of institution for betterment of stakeholders. The crucial role of head of institution for effective school environment is also discerned by Donahoe (1993). Similarly, Wolfson and Payne (2002) affirmed that "As a leader of a learning organization, the principal must motivate teachers to continue to grow professionally throughout their careers". Principals' positive attitude and support influence 
the motivation of teachers for their professional growth (Wideen, 1992; Meister 2010). As the result, the underlying hypothesis is proposed:

H3: Head influence impacts teachers' participation in Continuous Professional Development activities.

\subsection{Theoretical Framework}

Theory of Reasoned Action (Ajzen \& Fishbein, 1975)

As indicated by Courtney (1992) in literature that the theoretical model for participation of adults in continuous professional development mainly emphasis on sociological and psychological perspectives. On the other hand, Fishbein and Ajzen's employ Reasoned Action theory for sociological and psychological factors together and focus on the influence of societal and individual factors on decision to participate in learning activities (Gibson \& Becker, 1998). This theory used frequently in empirical studies having different population and site. This theory state that there are two determinants of individual's intension; personal attitude and social pressure which shapes their behaviour. McCamey (2003) illustrated the theory and specified that to motivate the individual two factors are important 1) his own desires and 2) encouragement by others.

Psychological Interaction Model (Merriam's \& Darkenwald, 1982)

External and internal motivators encourage the adults to take part in any activity. As per above mentioned theory the most powerful determinant for adult participatory behaviour is their socioeconomic status (National Center for Education Statistics, 1998). Additionally, Reder, Hart-landsberg and Wikelund, (1992) considered learning press as 'what is known' and emphasized on its importance. Similarly, (national center for education statistics, 1998) explain learning press of a person strengthen the specific behaviour and attitudes towards the importance of adult education. While Merriam and Darkenwald, (1982) identified four types of obstacles that influence the participation of individuals in learning i.e.; institutional, informational, situational and psychological barriers and gave DPS-G (Deterrents of Participation Scale). This scale helps to categories the general factors into six sub-factors i.e. low personal priority, lack of course relevancy, time constraints, lack of confidence, funding, and family, which affect the individuals' participation in learning opportunities.

\subsection{Conceptual Framework}

The conceptual model of current research is constructed on widespread literature review addressing the issue of teachers' participation in CPD (continuous professional development) programs and detects three main determinants taken from both above mentioned theories. First factor is 'time' taken from "Psychosocial Interaction Model by Darkenwald and Marriam's (1982)", second factor 'funding' also associated with from "Psychological Interaction Model by Darkenwald and Merriam's (1982)", while the third factor 'head influence' is linked with "Recruitment Paradigm, The Theory of Reasond Action by Ajzen and ishbein, (1975)". Therefore following hypothesis are formulated and tested how these factors i.e. time, funding and head of department influence participation of teachers in continuous professional development programs.

\section{Methodology}

The model to estimate the effect of time, funding and head influence on continuous professional development in parametric form is defined as follows:

$\mathrm{CPD}=\alpha_{\mathrm{o}}+\beta 1(\mathrm{~T})+\beta 2(\mathrm{~F})+\beta 3(\mathrm{HI})+\epsilon$

where T represents Time, F represent Funding, HI represents Head Influence and CPD represents Continuous Professional Development while $\alpha$ o represents constant and $\beta 1, \beta 2$ and $\beta 3$ are coefficients and $\epsilon$ is error term.

The model is estimated by the data collection through likert scale (5 point) questionnaire varies from "strongly disagree (1)" to "strongly agree (5)" adapted from two sources (Bayar A., 2013; Bugti F., 2018). Responses were individually obtained from 225 university teachers through google form. In questionnaire item 1 to 6 are related to time, from 7 to 11 linked with funding, from 12 to 15 are related to head influence and from 16 to 24 associated with continuous professional development of university teachers. 


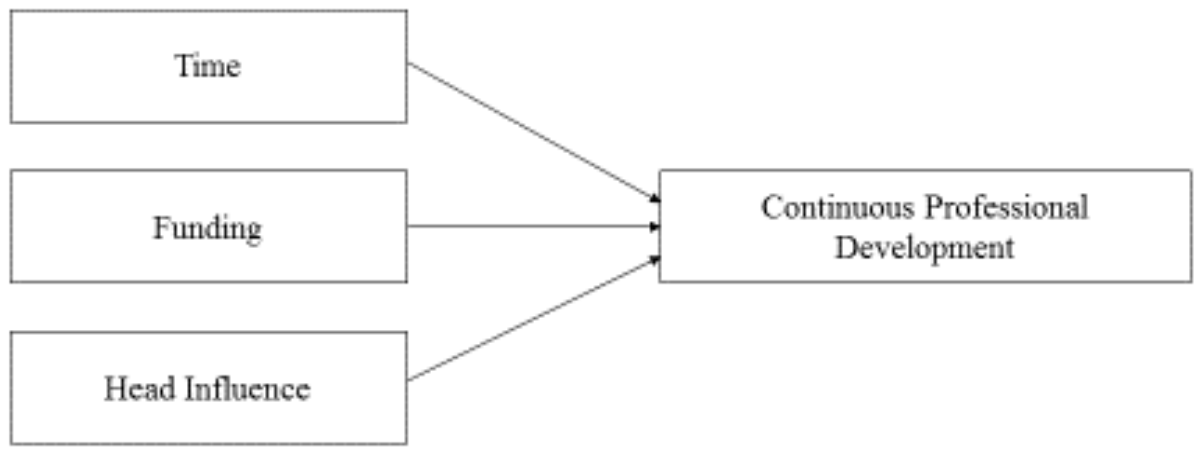

Figure No. 1. Model of study

\section{Data Analysis}

For data analysis different statistical tests in SPSS software was used to analyze the data.

\section{Reliability}

Statistical tests of reliability were applied to demonstrate the data reliability. The questionnaire for the study was based on 24 questions ( 15 questions of independent variables and 9 questions for dependent variable). Reliability test was applied in SPSS and the value of Cronbach's Alpha came out to be 0.932 (i.e.93.2\%) which shows that reliability of data is acceptable as per the limitations the value of Cronbach's Alpha should be more than 0.5 (i.e. $50 \%$ ).

TABLE I. Reliability Statistics

\begin{tabular}{|c|c|c|}
\hline Variable & No. of items & Cronbach's Alpha \\
\hline Time & 6 & 0.981 \\
\hline Funding & 5 & 0.972 \\
\hline Head Influence & 4 & 0.886 \\
\hline $\begin{array}{l}\text { Continuous } \\
\text { Development }\end{array}$ & 9 & 0.974 \\
\hline Overall & 24 & 0.932 \\
\hline
\end{tabular}

The first three variables 'Time', 'Funding' and 'Head Influence' was independent variables of the study having 6,5 and 4 items, respectively. The value of Alpha for 6 items of time is $0.981,5$ items of Funding is 0.972 and 4 items of Head Influence is 0.886 . The fourth variable 'Continuous Professional Development' was only dependent variable of this study. It had 9 items and the value of Alpha of these items is 0.974 . The overall reliability of the instrument is 0.932 .

\section{Factor analysis}

The value of KMO is 0.881 (> 0.7) which shows that the sample size is adequate for factor analysis. The sample size is significant for factor analysis as the value of significance in Bartlett's test is 0.000 . 
TABLE II. KMO and Bartlett's Test

\section{Kaiser-Meyer-Olkin Measure of Sample Adequacy. $\quad 0.881$}

\begin{tabular}{lll}
\hline & Approx. Chi-Square & 8949.987 \\
\hline \multirow{2}{*}{ Bartlett's Test of Spherity } & Df & 276 \\
\hline & Sig. & .000 \\
\hline
\end{tabular}

The following rotation component matrix was obtained after applying the test of Factor analysis:

TABLE III. Rotated Components matrix

\begin{tabular}{|c|c|c|c|c|}
\hline ITEMS & $\mathbf{T}$ & $\mathbf{F}$ & HI & CPD \\
\hline T1 & .952 & & & \\
\hline $\mathbf{T} 2$ & .947 & & & \\
\hline T3 & .944 & & & \\
\hline $\mathbf{T 4}$ & .947 & & & \\
\hline T5 & .946 & & & \\
\hline T6 & .937 & & & \\
\hline F1 & & .940 & & \\
\hline F2 & & .945 & & \\
\hline F3 & & .946 & & \\
\hline F4 & & .936 & & \\
\hline F5 & & .913 & & \\
\hline HI1 & & & .633 & \\
\hline HI2 & & & .755 & \\
\hline HI3 & & & .799 & \\
\hline HI4 & & & .810 & \\
\hline CPD1 & & & & .870 \\
\hline CPD2 & & & & .911 \\
\hline CPD3 & & & & .890 \\
\hline CPD4 & & & & .866 \\
\hline CPD5 & & & & .907 \\
\hline CPD6 & & & & .857 \\
\hline CPD7 & & & & .879 \\
\hline CPD8 & & & & .885 \\
\hline CPD9 & & & & .861 \\
\hline
\end{tabular}

The rotated component matrix is shown in above table and it illustrate that the highly correlated observed variables are group together and form a latent variable on the basis of value of factor loadings. According to the results, twenty-four observed variables are grouped together into four latent variables. 
Regression Analysis

TABLE IV. Regresion Coefficient

\begin{tabular}{lllll}
\hline Variable & Coefficient & t-stats & Prob. & V.I.F \\
\hline Constant & 11.715 & 7.102 & .000 & \\
\hline Time & .015 & .277 & .782 & 1.127 \\
\hline Funding & .063 & 1.147 & .253 & 1.107 \\
\hline Head Influence & .608 & 10.535 & .000 & 1.232 \\
\hline Adj. $\mathbf{R}^{\mathbf{2}}$ & & 0.394 & & \\
\hline F-stats & & 49.554 & & \\
\hline (Prob.) & $(0.000)$ & & \\
\hline
\end{tabular}

Table 4 shows variable with their beta value, co-linearity value and significance value. The significance value of time is 0.782 and funding is 0.253 which does not meet the threshold (i.e. $<0.05$ ) so hypothesis one and hypothesis two are not supported. While the significance value of head influence is 0.000 which meet the threshold (i.e. $<0.05$ ) so, hypothesis three was supported, showing that head influence impacts participation of teachers in CPD (continuous professional development) programs. VIF value of all three independent variables is greater than one which shows the clarity in multicollinearity (high correlation between independent variables). The value of adjusted $\mathrm{R}$ square is 0.394 , showing that $39.4 \%$ of the variance in continuous professional development can be predicted from time, funding and head influence. The value of F-stats is 49.55 and is significant indicating that the combination of the predictors significantly predicts continuous professional development. The $\beta$ value of head influence is more than that of time and funding. By using $\beta$ value from the above table we can write our equation as:

$\mathrm{CPD}=11.715+0.015(\mathrm{~T})+0.063(\mathrm{~F})+0.608(\mathrm{HI})+\epsilon$

\section{Model fitness and confirmatory factor Analysis}

Confirmation and modification of the model is done with analysis of model fitness for validation of dataset used for study. AMOS was used for CFA (confirmatory factor analysis). Figure No. 2 demonstrate the CFA test for all latent variables. All factor loadings were significant and greater than 0.5 , indicating strong convergent validity.

Three types of fit measure were used to verify the model's fitness; absolute fit measure that included $\chi^{2}$, RMSEA (Root Mean Square Error of Approximation), GFI (Goodness if index); incremental fit measures included AGFI (Adjusted goodness-of-fit index), NFI (Normed fit index), CFI (Comparative fit index), IFI (incremental fit index) and RFI (Relative fit index) and parsimony fit measures that included PNFI (Parsimony normed fit index) and PCFI (Parsimony comparative fit index) (Bollen, 1989; Hair et al., 2010).

Structural model is used to get empirical evidences to verify the relationship of variable hypothesized in the study. Indices of model-fit shows the adequacy and acceptance of current model $\chi 2 / \mathrm{df}=1.874(<3)$, RMSEA $=0.062(<0.08), \mathrm{AGFI}=0.830(>0.80), \mathrm{NFI}=0.952(>0.90), \mathrm{CFI}=0.977(>0.90), \mathrm{IFI}=0.977(>0.90), \mathrm{RFI}$ $0.944(>0.90)$, PNFI $=0.821(>0.50)$ and PCFI $=0.842(>0.50)$. These indices have among most frequently used, as they are less affected by sample size (Hair et al., 2010).

The results of path analysis indicated that head influence was positively related with continuous professional development of university teachers $(\mathrm{p}<0.05)$. Thus, hypothesis three was accepted. The $p$ value of Time and funding is not meeting the threshold level. So, hypothesis one and two are not supported

\section{Discussion}

Continuous professional development of teachers is a basic element as it enhances their skills, competencies and enables them to be helping hand for other. The research article intends to explore the factors that influence the continuous professional development of the teachers at university level. Time, funding and head influence was considered as independent variables and hypothesizes as influencing teachers' participation in continuous professional development activities. The research result shows that time and funding doesn't influence teachers' participation where as head influence was found significant. 


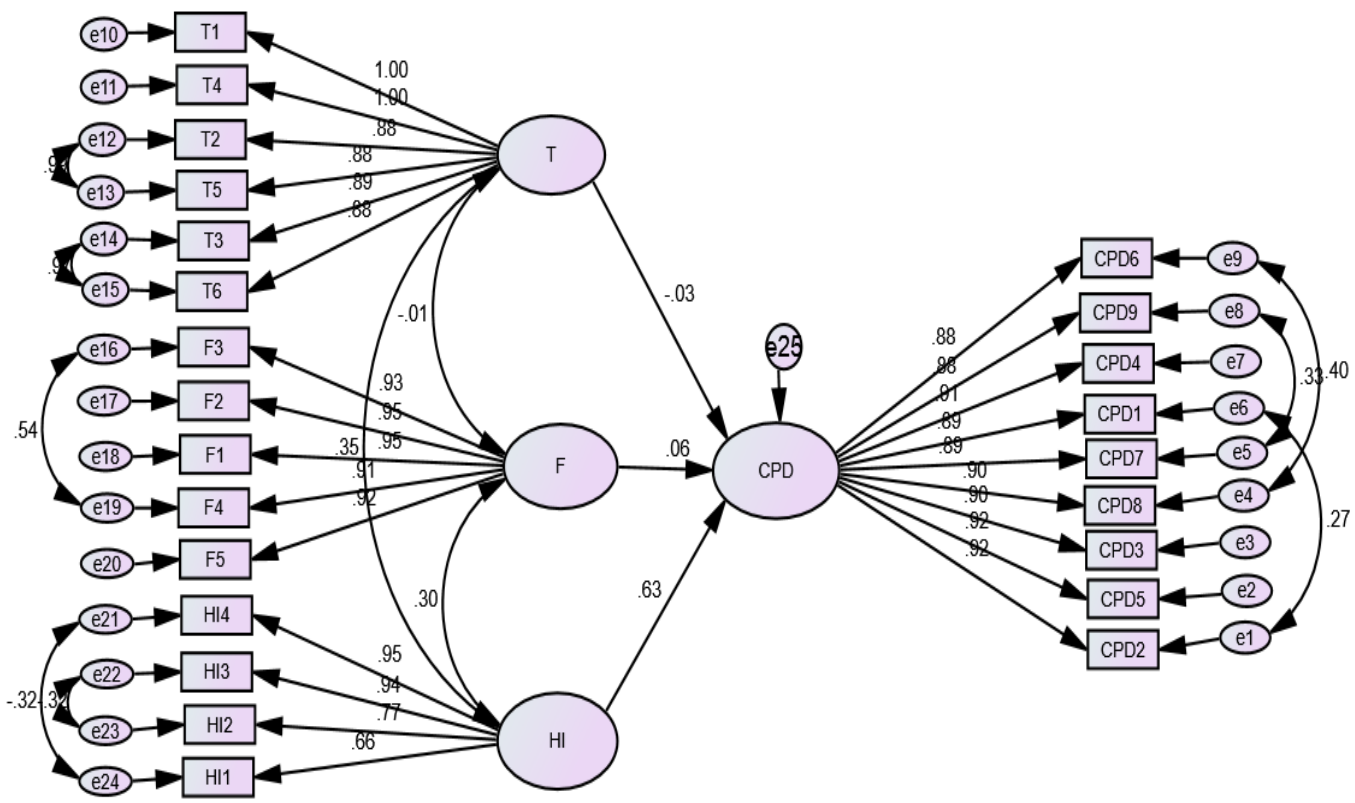

Figure No. 2. Structural Equation Model

The study found that the factor of time means the period spends in teaching learning activities and funding which means the financial support or budget does not affect the participation of university teachers in teachers continuous professional development activities where as the head influence which means the attitude, behaviour, conduct and approach of the head of the institution affects the participation of university teachers in teachers continuous professional development activities.

TABLE V. Goodness of fit indices for structural model

\begin{tabular}{lll}
\hline Fit indices & $\begin{array}{l}\text { Recommended } \\
\text { Level of fit }\end{array}$ & $\begin{array}{l}\text { Model } \\
\text { value }\end{array}$ \\
\hline Absolute fit measure & & 446.107 \\
\hline x2 (chi-square) & & 228 \\
\hline df (degrees of freedom) & $<3$ & 1.874 \\
\hline Chi-square/df (x2/df) & $<0.08$ & 0.062 \\
\hline RMSEA (Root Mean Square Error of Approximation) & & 0.830 \\
\hline Incremental fit measures & $>0.80$ & 0.952 \\
\hline AGFI (Adjusted goodness-of-fit index) & $>0.90$ & 0.977 \\
\hline NFI (Normed fit index), & $>0.90$ & 0.977 \\
\hline CFI (Comparative fit index) & $>0.90$ & 0.944 \\
\hline IFI (incremental fit index) & $>0.90$ & \\
\hline RFI (Relative fit index) & & 0.821 \\
\hline Parsimony fit measures & $>0.50$ & 0.842 \\
\hline PNFI (Parsimony normed fit index) & $>0.50$ & \\
\hline PCFI (Parsimony comparative fit index) & & \\
\hline
\end{tabular}


The test of multiple regression and confirmatory factory analysis supports and provided the evidence that time and funding does not influence on Continuous Professional Development of university teachers while head influence significantly effecting on it. Hence, head of institute play vital role for accomplishment of all professional development activities.

TABLE VI. Regression weights

\begin{tabular}{llllll}
\hline Path & B & SE & CR & p-value & Results \\
\hline $\mathbf{T} \rightarrow$ CPD & -0.21 & 0.042 & -0.513 & 0.608 & Not supported \\
\hline $\mathbf{F ~} \rightarrow$ CPD & 0.048 & 0.048 & 1.014 & 0.311 & No supported \\
\hline $\mathbf{H} \rightarrow$ CPD & 0.556 & 0.058 & 9.595 & $* * *$ & Supported \\
\hline
\end{tabular}

Continuous Professional Development (CPD) enhances competencies and skills of teachers that ensure the quality education therefore it is the demand of the age. According to the study by Bayar (2013) time is the most important and positively influencing factor on professional development activities in contrast the study of Lohman (2006) found that the continuous professional developmental activities are less influenced by time factor. Similarly, as per the results of this research the hypothesized statement that time influence the teachers' participation in continuous professional development activities was found insignificant. The second hypothesized statement about funding that it influences the teachers' participation in continuous professional development activities was also found insignificant that funding. Funding refers to financial support (Richardson, 1997). The third hypothesized statement about head influence that it impacts the teachers' participation in continuous professional development activities was found significant. Head of institution had an abundant influence on participation of teachers in CPD programs. Mclaughlin and Talbert, (2006) portrayed the idea that head is the one who can encourage or discourage the environment of institution for betterment of stakeholders. The crucial role of head of institution for effective school environment is also discerned by Donahoe (1993). The study of Meister (2010) affirmed that head's positive attitude and support influence the motivation of teachers for their professional growth. Another study by Adu and Okeke (2014) investigated the factors affecting the lecturers' participation in continuing professional development and they found that teachers are more likely to attend the continuous professional development activities of they are well motivated by their head of institution.

Current research is helpful for educators to avail the continuous professional development opportunities as per their convenient times and monetary incentives. This study provides evidence for positive head influence on continuous professional development of teachers. Therefore, it is recommended that head may support and encourage his/her team members to take part in continuous professional development activities. Moreover, this study also provide support to higher educational institutions to organize the continuous professional development programs by considering the external factors i.e. time, funding and head influence for fruitful results

\section{Conclusion}

This study addressed the questions that what are the factors that influence the continuous professional development activities of university teachers? For instance, how do time, funding and head of department influence participation of educators in professional development programs? However, this study focused to explore the factors that influence university teachers' participation in professional development programs. In this study on university teachers, the respondents shows more favorable attitude towards the head influence impact on continuous professional development activities of university teachers with significant value of 0.000 and expressed the less support to the factor of time and funding with an insignificant value of 0.782 and 0.253 , respectively. These findings demonstrate the importance of behavior of head that motivates the teachers to be professionally developed. The results also concerning considering the positive perception and attitude of heads' may increase the professional activities of teachers.

\section{REFERENCES}

Abadiano, H. L. \& Turner, J. (2004). Professional staff development: What works? The NERA Journal, 40(2), 87-91.

Ajzen, I. \& Fishbein, M. (1980). Understanding attitudes and predicting social behavior. Englewood Cliffs, NJ: Prentice Hall. 
Bayar, A., (2013). Factors affecting teachers' participation in professional development activities in turkey.

Becker, E. A., \& Gibson, C. C. (1998). Fishbein and Ajzen's theory of reasoned action: Accurate prediction of behavioral intentions for enrolling in distance education courses. Adult Education Quarterly, 49 (1), 43-55.

Birman, B., Desimone, Garet, M., \& Porter, A. (2000). Designing professional development that works. Educational Leadership, 57(8), 28-33

Bollen, K.A. (1989), Structural Equation with Latent Variables, John Wiley, New York, NY.

Borko, H. (2004). Professional development and teacher learning: Mapping the terrain. Educational Researcher, 33(8), 3-15.

Boydak, O. M., \& Dikici, A. (2001). Hizmet ici egitim programlarinin etkililiginin degerlendirilmesi.[The evaluation of the effectiveness of in-service training programs]. Firat Universitesi Sosyal Bilimler Dergisi, 11(2), 225240.

Bredeson, P. V. (2003). Designs for learning: A new architecture for professional development in schools. Thousand Oaks, CA: Corwin Press.

Bredeson, P. V., Scribner, J. P. (2000). A statewide professional development conference: Useful strategy for learning or inefficient use of resources. Education Policy Analysis Archives, 8(13).

Bugti, F., (2018). The impact of continuous professional development on teachers' competencies at higher education level.

Carver, C. L. \& Katz, D. S. (2004). Teaching at the boundary of acceptable practice: What is a new teacher mentor to do? Journal of Teacher Education, 55(5), 449462.

Collinson, V. \& Cook, T. F. (2000). “I don't have enough time” Teachers' interpretations of time as a key to learning and school change. Journal of Educational Administration, 39(3), 266- 281.

Collinson, V. \& Cook, T. F. (2004). Learning to share, sharing to learn: Fostering organizational learning through teachers' dissemination of knowledge. Journal of Educational Administration, 42(3), 312-332.

Corcoran, T. B. (1995). Helping teachers teach well: Transforming professional development. Consortium for Policy Research in Education, 1-11.

Courtney, S. (1992). Why adults learn. Towards a theory of participation in adult education. New York: Routledge.

Darkenwald, G.G. \& Merriam, S. B. (1982). Adult education: Foundations of practice. New York, NY: Harper and Row.

Darling-Hammond, L., \& Berry, B. (1998). Investing in teaching. Retrieved from Education Week on the Web (May 27).

Day, C. (1993). The importance of learning biography in supporting teacher development: An empirical study. In C. Day, J. Calderhead, \& P. Denicolo (Eds.), Research on teacher thinking: Understanding professional development. London: The Falmer Press.

Demirtas, Z. (2010). Ögretmeni hizmeticinde yetistirmenin bir araci olarak denetim [As a tool for training teacher inservice, supervision]. Electronic Journal of Social Sciences (Elektronik Sosyal Bilimler Dergisi), 9(31), 41-52.

Desimone, L. M., Porter, A. C., Garet, M. S., Yoon. K. S., \& Birman, B. F. (2002). Effects of professional development on teachers' instruction: Results from a three-year longitudinal study. Educational Evaluation and Policy Analysis, 24(2), 81-112.

Donahoe, T. (1993). Finding the way: Structure, time, and culture in school improvement. The Phi Delta Kappan, 75(4), 298-305.

Easton, L. B. (2008). From professional development to professional learning. Phi delta Kappan, 89(10), 755-761.

Fishbein \& Ajzen (1975). Belief, attitude, intention, and behavior: An introduction to theory and research. Reading, MA: Addison, Wesley.

Garet, M. S., Porter, A. C., Desimone, L., Birman, B. F., \& Yoon, K. S. (2001). What makes professional development effective? Results from a national sample of teachers. American Educational Research Journal, 38, 915-945.

Garet, M. S., Porter, A. C., Desimone, L. D., Birman, B. R, \& Yoon, K. S. (2002). What makes professional development effective? Results from a national sample of teachers. American Educational Research, 33(4), 915-945.

Gaunt, D. (1997). Building on the past: new opportunities for the profession. In H. Tomlinson (Ed.), Managing continuing professional development in schools. London: Paul Chapman Publishing.

Guskey, T. R. (1999). Apply time with wisdom. Journal of Staff Development. 20(2),10- 15.

Guskey, T. R. (2002). Professional development and teacher change. Teachers and Teaching: Theory and Practice, $8(3)$.

Guskey, T.R. (2003). What makes professional development effective? Phi Delta Kappan, 84( 10), 748-750. 
Hair, J.F., Black, W.C., Babin, B.J. and Anderson, R.E. (2010), Multivariate Data Analysis, 7th ed., Pearson, NJ.

Harris, A., Day, C., Goodall, J., Lindsay, G., \& Muijs, D. (2005). What different does it make? Evaluating the impacts of continuing professional development in schools.

Hering, W., \& Howey, K. (1982). Research in, on, and by teachers' centers. Occasional Paper No. 10. San Francisco, CA: Teachers' Center Exchange, Far West Laboratory for Educational Research and Development.

Hirsh, S. (2001). We're growing and changing. Journal of Staff Development, 22(3), 255- 258.

Hodkinson, H. \& Hodkinson, P. (2005). Improving schoolteachers' workplace learning. Research Papers in Education, 20(2), 109-131.

Jonson, K. F. (2002). Being an effective mentor: How to help beginning teachers succeed. Thousand Oaks, CA: Corwin Press.

Joyce, B., \& Showers, B. (1995). Student achievement through staff development: Fundamentals of school renewal. New York: Longman.

Klingner, J.K., Vaughn, S., Hughes, M.T., \& Arguelles, M. E. (1999). Sustaining research-based practices in reading: A 3-year follow-up. Remedial and Special Education, 20, 263-274.

Klingner, J. K. (2004). The science of professional development. Journal of Learning Disabilities, 37(3), 248-255.

Kwakman, K. (2003). Factors affecting teachers' participation in professional learning activities. Teaching and Teacher Education, 19, 149-170.

Le Metais, J. (1997). Continuing professional development: The European experience. In H. Tomlinson (Ed.), Managing continuing professional development in schools. London: Paul Chapman Publishing.

Leonard, L. \& Leonard, P. (2003). The continuing trouble with collaboration: Teachers talk. Current Issues in Education (Online), 6 (15).

Lohman, M. C. (2006). Factors influencing teachers' engagement in informal learning activities. Journal of Workplace Learning, 18(3), 141-156.

Loucks-Horsley, S., Hewson, P., Love, N., \& Stiles, K. (1998). Designing professional development for teachers of science and mathematics. Thousand Oaks, CA: Corwin.

McLaughlin MW 1997. Rebuilding teacher professionalism in the United States. In: A Hargreaves, R Evans (Eds.): Beyond Educational Reform, Bringing Lecturers Back. Buckingham: Open University Press, pp. 597-604.

McLaughlin. M. W., \& Talbert, J. E. (2006). Building school-based teacher learning communities: Professional strategies to improve student achievement. New York: Teacher College Press.

Meister, D., M. (2010). Experienced secondary teachers' perceptions of engagement and effectiveness: A guide for professional development. The Qualitative Report, 15(4), 880- 898.

Moir, E. \& Gless, J. (2001). Quality induction: An investment in teachers. Teacher Education Quarterly, 28(1), 109114. Retrieved February 17, 2010, from ERIC database.

Moss, B. \& Noden, H. (1994). What works for teaches in professional growth and development. The Reading Teacher, 47(8), 672-673.

Orhan, F. \& Akkoyunlu, B. (1999). Uzaktan egitim yaklasiminda temel egitim 1. kademe ogretmenlerininin video destekli hizmetici egitimi. [Video assisted in-service training program for primary education teachers]. Hacettepe Üniversitesi Eğitim Fakültesi Dergisi, 16-17, 134 - 141.

Payne, D. \& Wolfson, T. (2000). Teacher professional development: The principal's critical role. NASSO Bulletin, 84(13), 13-21.

Postholm, M., B. (2011). A completed research and development work project in school: The teachers' learning and possibilities, premises and challenges for further development. Teaching and Teacher Education, 27, 560-568.

Richard DuFour and Robert Eaker, Professional Learning Communities at Work: Best Practices for Enhancing Student Achievement (Blooming- ' ton, Ind.: National Education Service, 1998).

Richardson, J. (1997). Smart use of time and money enhances professional development. Journal of Staff Development, 46-49.

Richardson, V. (2003). The dilemmas of professional development. Phi Delta Kappan, 84(5), 401-406.

Rogers, M. P., Abell, S., Lannin, J., Wang, C-Y, Musikul, K., Barker, D., \& Dingman, S. (2007). Effective professional development in science and mathematics education: Teachers' and facilitators' views. International Jourzal of Science and Mathematics Education, 5, 507-532.

Rosenholtz, S. (1989). Teachers' workplace: The social organization of schools. New York: Longman.

Sandholtz, J. H. \& Scribner, S. P. (2006). The paradox of administrative control in fostering teacher professional development. Teaching and Teacher Education, 22, 1104-1117. 
Scanlan, C. L. (1986). Deterrents to participation: An adult education dilemma. Information Series No. 308, ERIC Clearinghouse on Adult, Career, and Vocational Education, Columbus, Ohio. Sponsoring Agency: Office of Educational Research and Improvement (ED), Washington DC. (ERIC \#ED272768).

Seferoglu, S. S. (2007). Professional teaching standards: The case of Turkish teacher candidates. World Applied Science Journal, 2(4), 412-419.

Shafer, F. K. (2009). An investigation of selected factors that influence middle-level teachers' professional development choices (Doctoral dissertation). Available from ProQuest Dissertations and Theses database. (UMI No. 3342322)

Sparks, D., \& Hirsch, S. (1997). A vision for staff development. Alexandria, VA: Association for Supervision and Curriculum Development.

Thompson, C. L. \& Zeuli, J. S. (1999). The frame and the tapestry: Standards-based reform and professional development. In L. Darling-Hammond \& G. Sykes (Eds.), Teaching as the learning profession: Handbook of policy and practice (pp 341-375). San Francisco: Jossey Bass.

Valentine, T. (1997). The United States of America: The current predominance of learning for the job. In P. Belanger \& S. Valdivielso (Eds.), The emergence of learning societies: Who participates in adult learning? (pp. 95-132). Oxford, UK: Pergamon and UNESCO Institute for Education.

Visser, T.C., Coenders, F. G. M., Terlouw, C., \& Pieters, J. M. (2010). Essential characteristics for a professional development program for promoting the implementation of a multidisciplinary science module. Journal of Science Teacher Education, 21, 623-642.

Van Woerkom, M., Nijhof, W. J., \& Nieuwenhuis, L.F. M. (2002). Critical reflective working behavior: a survey research. Journal of European Industrial Training, 26(8), 375-383.

Watts, G. D., \& Castle, S. (1993). The time dilemma in school restructuring. Phi Delta Kappan, 75(4), 306-310.

Wideen, M. F. (1992). School-based teacher development. In M. Fullan \& A. Hargreaves (Eds.), Teacher development and educational change (pp. 123-149). London: Falmer Press.

Wikelund, R. K., Reder, S., \& Hart-Landsberg, S. (1992). Expanding theories of adult literacy participation: A literature review. National Center on Adult Literacy.

Yamagata-Lynch, L. C. \& Haudenschild, M. T. (2009). Using activity systems analysis to identify inner contradictions in teacher professional development. Teaching and Teacher Education, 25, 507-517. 